\title{
Getting more light into the dark room of editorial conflicts of interest
}

\author{
Ana Marušić ${ }^{1}$, Rafael Dal-Rée
}

\footnotetext{
${ }^{1}$ Journal of Global Health and Department of Research in Biomedicine and Health, University of Split School of Medicine, Split, Croatia

${ }^{2}$ Epidemiology Unit, Health Research Institute-Fundación Jiménez Díaz University Hospital, Universidad Autónoma de Madrid, Madrid, Spain
}

\begin{abstract}
A current standard in research is declaration of financial and nonfinancial conflicts of interest (CoI) related to the research process and the publication of results. However, policies on disclosing re- searchers' CoI introduced by research funders, such as the National Institutes of Health (NIH) in the USA, do not work in practice [1] and there are calls for the creation of publicly accessible registries of researchers' CoI [2]. Journals have also developed CoI policies for authors, who present the results of their research in journals, and for peer reviewers, who participate in the evaluation of the work submitted to the journal $[3,4]$.

What about journal editors, who may also have competing interests in relation to submitted manuscripts and even be authors on manuscripts submitted to their own journals? The International Committee of Medical Journal Editors (ICMJE) recommends that journal editors publicly disclose their potential CoI [3]. However, a number of studies demonstrate that journal editors in general do not follow the policies they impose on authors and reviewers.

Studies presented in Table 1 clearly show that the transparency of disclosure of editorial CoI has not improved across journals from a range of disciplines and influence in the scientific community in the last 12 years, despite greater awareness and the published evidence about the problem [3]. With the availability of the information on payments to physicians in the US through the Physician Sunshine Act from August 2013, it also became clear that physician-editors working as clinicians in the US received industry payments for their professional and research work $[13,15-17]$. This practice seems to be particularly common for high impact journals, both in general/internal medical and specialty disciplines (Table 1). The payments to editors varied a lot both between and within journals of different medical fields. For example, although the same percentage (28\%) of physicians working as editors in 4 general/internal medicine journal received general payments (eg, consultancy, expert opinion, travel) from industry in 2014, the mean and the maximum payments received by editors of the New England Journal of Medicine and JAMA were 72 times (US\$3899 vs US\$54) and 100 times (US\$78617 vs US\$795) higher that those received by editors of JAMA Internal Medicine and Annals of Internal Medicine, respectively [13]. 76\% of cardiology journal editors and $56 \%$ of surgery journal editors received general industry payments, with the mean payment of US\$225556 and US\$246, respectively, and the maximum payments of US\$10981 153 and US\$1922, respectively [13]. Another analysis showed that 10\%, 44\% and 2\% editors of internal medicine, cardiology and surgery journals with the highest number of citations in 2015 per specialty received more than US\$10000 as general payments from industry, respectively [17].
\end{abstract}


Table 1. Disclosures of editorial conflicts of interests (CoI) and payments to editors in biomedical journals*

\begin{tabular}{|c|c|c|}
\hline Study (Authors, year) & JOURNALS INCLUDED & Finding \\
\hline \multicolumn{3}{|l|}{ Declaration of CoI: } \\
\hline Cooper et al., 2006 [5] & $\begin{array}{l}91 \text { high-impact general and specialty biomedical } \\
\text { journals }\end{array}$ & $40 \%$ of the journals stated that they had CoI policies for editors \\
\hline Bhargava et al., 2007 [6] & 12 gastroenterology and hepatology journals & $17 \%$ of the journals publicly disclosed editorial CoI \\
\hline Andraku et al., 2009 [7] & 42 ophthalmology journals & $5 \%$ of the journals publicly disclosed editorial CoI \\
\hline Alfonso et al, 2012 [8] & $\begin{array}{l}45 \text { European Society of Cardiology National } \\
\text { Cardiovascular Journals }\end{array}$ & $18 \%$ of the journals had a specific policy on editors' CoI \\
\hline Qureshi et al., 2012 [9] & 15 gastroenterology and hepatology journals & $33 \%$ of the journals publicly disclosed CoI policies for editors \\
\hline Smith et al., 2012 [10] & 10 high-impact medical journals & $40 \%$ of the journals have easily accessible CoI policies for editors \\
\hline Bosch et al., 2013 [11] & 399 high-impact biomedical journals & $39 \%$ of the journals required editors' CoI disclosures \\
\hline Broga et al., 2014 [12] & $\begin{array}{l}68 \text { biomedical journals from Southeast and Eastern } \\
\text { Europe }\end{array}$ & $3 \%$ of the journals had CoI policies for editors \\
\hline Liu et al., 2017 [13] & 52 influential US medical journals from 25 specialties & $33 \%$ of the journals had readily available editors' CoI policies \\
\hline Yang et al., 2017 [14] & $\begin{array}{l}30 \text { Chinese-language and } 37 \text { English-language } \\
\text { journals in China }\end{array}$ & $\begin{array}{l}\text { No Chinese-language journals had CoI policies for editors; 50\% } \\
\text { of editorials in English-language journals had CoI disclosure }\end{array}$ \\
\hline \multicolumn{3}{|c|}{ Payments received by editors: } \\
\hline Liu et al., 2017 [13] & $\begin{array}{l}713 \text { editors from } 52 \text { influential US medical journals } \\
\text { from } 25 \text { specialties }\end{array}$ & $\begin{array}{l}51 \% \text { of the editors received general and } 19.5 \% \text { research } \\
\text { payments in } 2014\end{array}$ \\
\hline $\begin{array}{l}\text { Mehlman et al., } 2017 \\
\text { [15] }\end{array}$ & 15 orthopaedic surgery journals & $4-73 \%$ of editorial board members received $>$ US $\$ 10000$ in 2014 \\
\hline Verma, 2017 [16] & $\begin{array}{l}85 \text { editorial board members from } 3 \text { US radiation } \\
\text { oncology journals }\end{array}$ & $\begin{array}{l}76 \% \text { of the editorial board members received payment in } \\
2013-2015\end{array}$ \\
\hline Wong et al., 2017 [17] & $\begin{array}{l}333 \text { editorial board members from } 35 \text { highly cited } \\
\text { medical journals from } 7 \text { specialties }\end{array}$ & $\begin{array}{l}\text { 64\% editorial board members received any industry-associated } \\
\text { payments in 2013-2016 }\end{array}$ \\
\hline
\end{tabular}

*Articles were identified in PubMed, Scopus, arXiv.org, PeerJ preprint and F1000 Resarch on 24 March 2018 by using the search key-words "conflict(s) of interest", "competing interest(s)", "declaration(s)" and "payment(s)" in combination with the key-word "editor(s)"

Why is disclosure of industry payments to editors relevant? Evidence shows that industry payments, even if they are modest, such as for meals, are associated with higher rates of prescription of brand-name medicines although generic drugs of similar efficacy are available, as well as greater expenditure on prescriptions per patient [18-21]. This means that editors who received industry payments, regardless of the amount, can make biased decisions, too, although sometimes in the opposite direction to the expected one [22]. On the other hand, the individuals do not like being considered biased, and mandating disclosure of potential CoI may be an incentive to avoid them [23].

The ICMJE states that any journal editor with a potential CoI should recuse himself or herself from editorial decisions affecting manuscripts that are considered for publication, especially when the editor is the author of the submitted work. The editor-in-chief must also know the potential CoI of the members of the editorial team and make them public on a regular basis [3]. Thus, the editorial CoI policy places the three main actors of the editorial process - authors, external reviewers and editors on the same level of the transparency demand. Unfortunately, the member journals of the ICMJE also do not follow well their own recommendations. We checked the availability of policies for declaring CoI for authors, reviewers and editors in the public domain, ie, at the journal web-pages, as well as the existence of public declaration of individual CoIs by journal editors (Table 2).

While all 14 ICMJE member journals had detailed CoI declaration policies for authors, only 36\% (5/14) had easily available policies for declaring reviewers' CoIs, and those that use open peer review system (eg, BMJ) also publish CoI declaration for individual reviewers together with the relevant article. Only 36\% (5/14) ICMJE member journals had publicly disclosed policies about managing editorial CoIs and 2 publicly posted declarations of current individual CoI for their editors. It is possible that those ICMJE-member journals that do not publicly disclose their editors' individual CoI follow them internally when appropriate, but this would be against ICMJE recommendations for the transparency of CoI disclosures.

What can be done in the situation where we have so many good policies but so few actual application in practice? First, the ICMJE member journals should make sure that all recommended policies are fully implemented, so that they set real standards and examples for the editorial community. The policies on editorial CoI and declarations of individual CoIs for editors should be posted and easily identifiable on journal's web pages. Transparency of editor's CoI could be further increased by publishing individual ed- 
Table 2. Conflict of interest (CoI) policies of journal members of the International Committee of Journal Editors (ICMJE)*

\begin{tabular}{|c|c|c|c|c|c|}
\hline \multirow[t]{2}{*}{ JouRAMAL } & \multirow[t]{2}{*}{ OWNER, COUNTRY } & \multicolumn{2}{|c|}{ Col policy for: } & \multicolumn{2}{|c|}{ Entrors' Col declaration } \\
\hline & & Authors & Reviewers & Policy & $\begin{array}{l}\text { Individual } \\
\text { declarations }\end{array}$ \\
\hline Annals of Internal Medicine & American College of Physicians, USA & Yes & Yes & No & No \\
\hline BMJ & British Medical Association, UK & Yes & Yes & Yes & Yes \\
\hline Bulletin of the WHO & World Health Organization, Switzerland & Yes & No & No & No \\
\hline Deutsches Ärzteblatt & German Medical Association, Germany & Yes & No & No & No \\
\hline Ethiopian Journal of Health Sciences & Jimma University, Ethiopia & No & No & No & No \\
\hline Iranian Journal of Medical Sciences & Shiraz University of Medical Sciences, Iran & Yes & Yes & Yes & No \\
\hline JAMA & American Medical Association, USA & Yes & No & Yes & No \\
\hline Journal of Korean Medical Science & $\begin{array}{l}\text { Korean Academy of Medical Sciences, Korean Medical } \\
\text { Association, South Korea }\end{array}$ & Yes & No & No & No \\
\hline Lancet & Elsevier, UK & Yes & No & No & No \\
\hline New England Journal of Medicine & Massachusetts Medical Society, USA & Yes & Yes & Yes & No \\
\hline New Zealand Medical Journal & New Zealand Medical Association, New Zealand & Yes & No & No & No \\
\hline PLOS Medicine & Public Library of Science, USA & Yes & Yes & Yes & Yes \\
\hline Revista Médica de Chile & Sociedad Médica de Santiago, Chile & Yes & No & No & No \\
\hline Ugeskrift for Laeger & Danish Medical Association, Denmark & Yes & No & No & No \\
\hline
\end{tabular}

*Web pages of all ICMJE journals were searched in April 2018. For journals published in more than language, only the English version was searched

itorial CoI declarations in the journal. In this way, such published item would be indexed in bibliographical databases, clearly visible and properly archived. Annual publication of editorial CoI declarations would ensure that possible changes are recorded or CoI declaration of new editors made public.

Publications of editorial CoI declaration is already the practice in some journals. Table 3 presents the examples of editorial CoI declarations published as editorials or statements in journals and indexed in PubMed. It can be imagined that such declarations could be indexed with a specific tag, similar to those used to mark specific types of publications in MEDLINE [24], which could make them easily identifiable in bibliographical databases. In this way, disclosures of editorial CoI would reach the level of transparency required for all stakeholders in the publication process.

Table 3. Examples of individual conflict of interest declarations by journal editors indexed as separate bibliographical items in PubMed JoURMAL RaFEREMG: Statiament if avalabie as abstragt in Pubiliad

[No authors listed]. Financial disclosure for associate editors of the Cleveland Clinic Journal of Medicine. Cleve Clin J Med. 2010;77: 347 .

[No authors listed]. Headache associate editors declaration of conflicts of interest. Headache. 2014:54:4-6.

Lubowitz JH. Editorial commentary: Editor's conflict of interest.

Arthroscopy. 2015;31:1740

The Editor-in-chief has recused himself from industry consulting, which he performed before assuming the position, and returned related royalties and divested related stock options, in order to mitigate against conflict-of-interest. The Editor discloses affiliation with an institution that receives support from diverse industry partners in support of research and education.

[No authors listed]. Conflict of Interest Declarations by Contributing Editors of the Special Issue on Early-Career Systems Microbiology Scientists, Sponsored by Janssen Human Microbiome Institute (JHMI). mSystems. 2018 Mar 6;3(2). pii: e00010-18.

Rey C, on behalf of Anales de Pediatría editorial team. Conflicts of interest of the editors. (article in Spanish). An Pediatr (Barc). 2018;88:296-7.

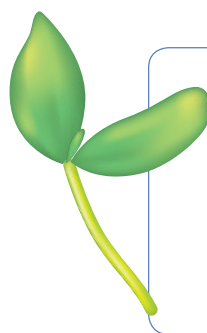

Funding: None.

Authorship declaration: AM and RDR equally contributed to the manuscript.

Conflicts of interest: AM declares that she participated in the creation of the ICMJE Form for Disclosure of Potential Conflicts of Interest, and that she is the Coeditor in Chief of the Journal of Global Health. RDR declares no conflicts of interest. 
1 Reardon S. NIH disclosure rules falter. Nature. 2015;525:300-1. Medline:26381962 doi:10.1038/525300a

2 Dunn AG, Coiera E, Mandl KD, Bourgeois FT. Conflict of interest disclosure in biomedical research: a review of current practices, biases, and the role of public registries in improving transparency. Res Integr Peer Rev. 2016;1:1. Medline:27158530 doi:10.1186/s41073-016-0006-7

3 International Committee of Medical Journal Editors. Recommendations for the conduct, reporting, editing, and publication of scholarly work in medical journals. Available at: http://www.icmje.org/recommendations/browse/roles-and-responsibilities/author-responsibilities-conflicts-of-interest.html.

4 Nature Editors. Outside interests. Nature Research journals will ask authors to declare non-financial conflicts. Nature. 2018;554:6. Medline:29388964 doi:10.1038/d41586-018-01420-8

5 Cooper RJ, Gupta M, Wilkes MS. Hoffman JRl. Conflict of interest disclosure policies and practices in peer-reviewed biomedical journals. J Gen Intern Med. 2006;21:1248-52. Medline:17105524 doi:10.1111/j.1525-1497.2006.00598.x

6 Bhargava N, Qureshi J, Vakil N. Funding source and conflict of interest disclosures by authors and editors in gastroenterology specialty journals. Am J Gastroenterol. 2007;102:1146-50. Medline:17531007 doi:10.1111/j.1572-0241.2007.01268.x

7 Anraku A, Jin YP, Trope GE, Buys YM. Survey of conflict-of-interest disclosure policies of ophthalmology journals. Ophthalmology. 2009;116:1093-6. Medline:19376583 doi:10.1016/j.ophtha.2008.12.053

8 Alfonso F, Timmis A, Pinto FJ, Ambrosio G, Ector H, Kulakowski P, et al; Editors' Network European Society of Cardiology Task Force. Conflict of interest policies and disclosure requirements among European Society of Cardiology National Cardiovascular Journals. Eur Heart J. 2012;33:587-94. Medline:22383145 doi:10.1093/eurheartj/ehr464

9 Qureshi J, Sud A, Vakil N. Funding source and conflict of interest disclosures by authors and editors in gastroenterology specialty journals revisited. Aliment Pharmacol Ther. 2012;35:690-5. Medline:22257079 doi:10.1111/j.1365-2036.2011.04989.x

10 Smith E, Potvin MJ, Williams-Jones B. Accessibility and transparency of editor conflicts of interest policy instruments in medical journals. J Med Ethics. 2012;38:679-84. Medline:22556312 doi:10.1136/medethics-2012-100524

11 Bosch X, Pericas JM, Hernández C, Doti P. Financial, nonfinancial and editors' conflicts of interest in high-impact biomedical journals. Eur J Clin Invest. 2013;43:660-7. Medline:23550719 doi:10.1111/eci.12090

12 Broga M, Mijaljica G, Waligora M, Keis A, Marusic A. Publication ethics in biomedical journals from countries in Central and Eastern Europe. Sci Eng Ethics. 2014;20:99-109. Medline:23456142 doi:10.1007/s11948-013-9431-x

13 Liu JJ, Bell CM, Matelski JJ, Detsky AS, Cram P. Payments by US pharmaceutical and medical device manufacturers to US medical journal editors: retrospective observational study. BMJ. 2017;359:j4619. Medline:29074628 doi:10.1136/ bmj.j4619.

14 Yang L, Wang P, Yang R. Conflict of interest reporting in biomedical journals published in China. Account Res. 2017;24:4517. Medline:29083932 doi:10.1080/08989621.2017.1392246

15 Mehlman CT, Okike K, Bhandari M, Kocher MS. Potential financial conflict of interest among physician editorial board members of orthopaedic surgery journals. J Bone Joint Surg Am. 2017;99:e19. Medline:28244918 doi:10.2106/ JBJS.16.00227

16 Verma V. Financial relationships with industry of editorial board members of the three journals of the American Society for Radiation Oncology. Int J Radiat Oncol Biol Phys. 2017;99:286-91. Medline:28871971 doi:10.1016/j.ijrobp.2017.03.020

17 Wong VSS, Avalos LN, Callaham ML. Industry payments to physician journal editors. Peer J preprints. 20 October 2017. [8 February 2018]. https://peerj.com/preprints/3359/

18 Perlis RH, Perlis CS. Physician payments from industry are associated with greater Medicare part D prescribing costs. PLoS One. 2016;11:e0155474. Medline:27183221 doi:10.1371/journal.pone.0155474

19 Fleischman W, Agrawal S, King M, Venkatesh AK, Krumholz HM, McKee D, et al. Association between payments from manufacturers of pharmaceuticals to physicians and regional prescribing: cross sectional ecological study. BMJ. 2016;354:i4189. Medline:27540015 doi:10.1136/bmj.i4189

20 DeJong C, Aguilar T, Tseng C-W, Lin GA, Boscardin WJ, Dudley RA. Pharmaceutical industry-sponsored meals and physician prescribing patterns for medicare beneficiaries. JAMA Intern Med. 2016;176:1114-22. Medline:27322350 doi:10.1001/jamainternmed.2016.2765

21 Wood SF, Podrasky J, McMonagle MA, Raveendran J, Bysshe T, Hogenmiller A, et al. Influence of pharmaceutical marketing on Medicare prescriptions in the District of Columbia. PLoS One. 2017;12:e0186060. Medline:29069085 doi:10.1371/journal.pone.0186060

22 Loewenstein G, Sah S, Cain DM. The unintended consequences of conflict of interest disclosure. JAMA. 2012;307:66970. Medline:22337676 doi:10.1001/jama.2012.154

23 Sah S, Loewenstein G. Nothing to declare. Mandatory and voluntary disclosure leads advisors to avoid conflicts of interest. Psychol Sci. 2014;25:575-84. Medline:24379156 doi:10.1177/0956797613511824

24 National Library of Medicine. Fact Sheet. Errata, retractions, and other linked citations in PubMed. Available: https:// www.nlm.nih.gov/pubs/factsheets/errata.html. Accessed 16 April 2018. 